PROBLEMS

OF MANAGEMENT

IN THE $21^{\text {st }}$ CENTURY

Volume 7, 2013

\section{RISK IDENTIFICATION TOOLS - POLISH MSMES COMPANIES PRACTICES}

\author{
Iwona Gorzeń-Mitka \\ Czestochowa University of Technology, Czestochowa, Poland \\ E-mail: iwona.mitka@zim.pcz.pl
}

\begin{abstract}
The purpose of this study is to present risk identification tools in Polish micro, small and medium-sized enterprises (MSMEs). Risk identification is a key element of the risk management process in companies. Correctly fitting risk identification tools affect the accuracy of management decisions. The result of research is to identify the leading risk identification tools used by MSMEs. The study was conducted in 2010-2012 using a mixed survey-monographic method and questionnaires. The qualitative data were obtained during the study.
\end{abstract}

Key words: risk management, risk identification, micro, small and medium enterprises (MSMEs).

\title{
Introduction
}

Exploring the decision-making mechanisms of micro, small and medium enterprises (MSMEs) is one of the key areas of economic research. MSMEs, which constitute over $90 \%$ of enterprises in all countries, are an important source of manufacturing and employment. They employ $33 \%$ of workers in low-income countries and $62 \%$ of workers in high-income countries (Vandenberg, 2009, p. 8). In Poland, the importance of this sector is even greater. MSMEs constitute over 99 percent of the total number of entities (94 percent of them are micro entities) and participate in the creation of more than 46 percent of gross domestic product. The largest share of this group is micro entities, which in 2008 formed 29.8 percent of GDP (GUS, 2011, p. 36; PARP, 2010.). At the same time they belong to a group of companies particularly sensitive to changes in the market environment. Therefore, research on risk awareness and behavior in this area among the group appear to be particularly reasonable.

The presented research continues the author's discussion on risk management in the Polish MSMEs publicized in "Risk Management in Polish Companies" (Gorzeń-Mitka, 2012). Therefore, the paper includes:

1. Literature review on risk management and risk identification methods and tools;

2. MSMEs practice indicators in the highlighted elements of the risk management process - risk identification.

\section{Risk Identification Tools - Literature Review}

The issue of risk management in organizations, although extensively discussed on the international level (Beasley et al. 2005; Chapman 2007; Economist Intelligence Unit 2010; FERMA 2010, Liebenberg et al. 2003), is an insufficiently discussed and recognized area in Poland, particularly in economic practice (Gorzeń-Mitka, 2007; Gorzeń-Mitka, 2011, p. 322329). World practice shows that risk management has now become an integral part of business activities undertaken by the company, builds value to the organization, shaping the effectiveness of undertaken actions (Hopkin, 2010; Lam, 2003). 
It should be noted that the literature clearly indicates that risk management is still in the early stages of development. In particular, this applies to MSMEs sector.

Risk identification is one of the key steps in the risk management process. Its purpose is to detect potential events that may affect the realization of its objectives. A risk identification process seeking out the potential source of problems, or with the problem itself, is based on a source analysis (risk sources may be internal or external to the system that is the target of risk management), problem analysis (risks are related to identified threats), or event basis (Spedding, Rose, 2008, p. 69). A clear method of risk identification and evaluation accepted by an organization creates the grounds for the manner of risk management (Karkoszka, 2013, p. 7). Appropriate selection tools at this stage determine the quality of the data received. At the same time, identified risks are the basis for analysis in the next stages of the risk management process (risk assessment, risk response, etc.). This, in turn, directly influences the correctness in decision-making.

Recommendations for using tools to identify risks are presented comprehensively in the ISO 31010 „Risk management - Risk assessment technique” standard (ISO, 2009b). Risk identification techniques can be often found in the literature as well. The most frequently indicated are: brainstorming, Delphi Technique, Influence Diagram, interview (expert judgment), checklist, Nominal Group Technique, flowcharts, pondering, Root Cause Identification, Cause-andEffect Diagram, questionnaire, SWOT Analysis, synectics, Case Based Approach, Electronic Brainstorming, What if? SWIFT structure, HAZOP, Business Impact Analysis (Martines, et al. 2011, p. 244; Spedding, Rose, 2008, p. 69).

Recognition of risks and methods' awareness as well as methods of dealing with it by MSMEs are the major subjects of research undertaken by the author. The basis for assessment of risk management awareness level in the target group of entrepreneurs in this publication are indications of the respondents regarding the identification of key risks in the organization.

\section{Methodology of Research}

Study on risk management in micro and small enterprises was carried out in the first half of 2010 (survey I), in the first half of 2011 (survey II) and in the first half of 2012 (survey III) among the same group of entities operating in the sub-Silesian region of Czestochowa. Due to the low awareness of risk management proven in previous author's studies, decisions were taken to use purpose-random selection of entities engaging in an area of interest. The statistical material for the study was gathered through partial studies carried out by a purpose-random selection of statistical collective of SME sector from Czestochowa subregion. Due to the nonrandom sampling and sample size, the results and conclusions apply only to the companies in the study. Although the small number of responses indicates that the sample is not representative, some general conclusions can be drawn, since the purpose was to conduct exploratory research. Low response level was expected due to the nature of the research and constantly low interest in the topic of risk management.

The study was conducted using a mixed survey-monographic method. The main research technique was a questionnaire. The questionnaire included 30 questions. The questions were closed, however respondents could suggest their own answer, deviating from the proposed ones, in the "other, please specify" option. 483 entities were selected for a study. 54 of them expressed consent to participate in survey I, in survey II - 47 and in survey III - 106. The analysis included 49 surveys in study I, in study II - 40 surveys and in study III - 103 (questionnaires sent by other entities were filled in incorrectly or incompletely). The structure of respondents presented Table 1. 
Iwona GORZEŃ-MITKA. Risk Identification Tools - Polish MSMES Companies Practices

PROBLEMS

OF MANAGEMENT

IN THE $21^{\text {st }}$ CENTURY

Volume 7, 2013

8 Table 1. Structure of respondents of studies (in \%).

\begin{tabular}{llll}
\hline Specification & $\begin{array}{l}\text { Study I } \\
\mathrm{N}=49\end{array}$ & $\begin{array}{l}\text { Study II } \\
\mathrm{N}=40\end{array}$ & $\begin{array}{l}\text { Study III } \\
\mathrm{N}=103\end{array}$ \\
\hline Micro-entities & 41 & 75 & 76 \\
Small businesses & 19 & 10 & 18 \\
Medium-sized enterprises & 33 & 15 & 6 \\
\hline
\end{tabular}

Source: own study

In both studies, a leading group of respondents were micro-entities. Surveyed entities carried out their activities in various areas: production, trade and services. The involvement of production often involves activities in the area of trade. The companies participating in the study were mainly manufacturers offering their final products. This is undoubtedly related to the specificity of the Silesian industrial area. The frequency analysis method was used for data interpretation.

\section{Results of Research (Risk Identification Tools in MSMES Practices)}

Organizations, taking part in the research, indicated that they were considering the consequences that may result in the risks they were identifying - 59\% (survey I) $(70 \%$ micro and $56 \%$ of small businesses), $28 \%$ (survey II) (30\% micro and $20 \%$ of small businesses) and $34 \%$ (survey III) (43\% micro and $23 \%$ of small businesses). However, only $24 \%$ organizations (survey I), $18 \%$ (survey II) and $21 \%$ (survey III) were considering the causes (sources) of the risks. The consequence of the key risk ranking - where a significant group of identified risks are the internal risks, depending on how the organizations function - seems to be worrisome.

Such inconsistencies were observed during the research to identify the extent of the risks relevant to the organization. The respondents, in two separate questions, had to indicate whether comprehensive and systematic identification of risks is conducted in all areas of their business and whether their company keeps a register of risks.

With regards to the first question, $49 \%$ MSMEs (survey I) and in this $50 \%$ micro and $44 \%$ small entities (with respectively $20 \%$ and $11 \%$ answered "no opinion") emphasized that their companies conducted a systematic and comprehensive review of risks.

On the other hand, in answer to the second question, 82\% MSMEs (85\% micro and $89 \%$ of small entities) admitted that they did not keep the register of risks occurring.

In study II, 33\% of MSMEs reported they were making a comprehensive and systematic identification of risks. At the same time, $90 \%$ claimed that they do not keep any register of risks.

In study III, the entities showed a greater knowledge of the issues of risk identification. $87 \%$ subjects did not have a systematic identification of threats and $93 \%$ did not keep a register of risks. The responses to these two questions in study I and II indicated significant differences (which proved a misunderstanding of the nature of the risk identification), where as in study III responses were significantly correlated. The conclusion is: the awareness of risk identification tools are systematically growing.

The data indicates a low level of basic knowledge on the construction of the risk management process in the organization. The reason for this is that - among other things - in the latest risk management standard, ISO 31000:2009 (ISO 2009a), risk register is a key element of building an effective risk management system in an organization. Counterweight to the above, however, may be a claim that $65 \%$ (survey I), $70 \%$ (survey II) and $73 \%$ (survey III) of companies declared that their actions in the identification of risks are considered to be effective.

The study showed the intuitiveness of activities related to key areas of uncertainty in the organization. The basic tools used to identify risks were the previous experience of management, brainstorming and SWOT analysis. The respondents were presented 10 tools used in the field of European business practices. 
Table 2. Risk identification tools and techniques (\% of responses, max. 3 answers).

\begin{tabular}{lllll}
\hline \multirow{2}{*}{ Specification } & $\mathbf{2 0 1 0}$ & $\mathbf{2 0 1 1}$ & $\mathbf{2 0 1 2}$ & $\begin{array}{l}\text { Average 2010-2012 } \\
\text { (Ranking) }\end{array}$ \\
\cline { 2 - 5 } & & & & \\
\hline Previous experience & 78 & 68 & 83 & $76(1)$ \\
\hline Documents review & 43 & 50 & 52 & $48(2)$ \\
\hline Brainstorming & 39 & 28 & 51 & $39(3)$ \\
\hline Opinions of experts (Delphi Technique) & 31 & 20 & 33 & $28(4)$ \\
\hline Process analysis & 31 & 20 & 19 & $23(5)$ \\
\hline Surveys / Polls & 10 & 18 & 11 & $13(8)$ \\
\hline SWOT analysis & 37 & 13 & 12 & $21(6)$ \\
\hline Interview / Discussion & 12 & 10 & 10 & $11(9)$ \\
\hline Focus groups & 29 & 5 & 8 & $14(7)$ \\
\hline Simple modeling & 6 & 0 & 7 & $4(10)$ \\
\hline Source: own study & & & & \\
\end{tabular}

Most of the surveyed companies identified several tools used in this area, however, as presented in Table 2, the experience and intuition are the primary way to identify risks. Most often MSMEs rely on their own experience in identifying risks. This result may be caused by lack of knowledge and skills in the use of other tools, beliefs in their low efficiency or conviction of the high cost of their application.

For example, the study "Risk identification techniques knowledge and application in the Brazilian construction" (Martines et al., 2011) shows that the main tools for identifying risks are checklist, flowchart and brainstorming.

\section{Discussion}

Consideration of risk in decision-making is now becoming an important element influencing the effectiveness of the organization (Bernstein, 1996). The survey showed that the risk identification techniques are previous experience, documentation review and brainstorming. This result is significantly different from the list of identification techniques described in the literature. For example, the study "European Risk Management FERMA Benchmarking Survey 2010" shows that the main tools for risk identification and measurement are workshops, internal and external risk records, scenario analysis, Value at Risk and stochastic models (FERMA 2010, p. 27). Brainstorming, one of the most frequently indicated risk identification techniques, has been identified only as a third. In addition, it is clear that among the participants there is no overall knowledge of the techniques described in literature that might be applied to identify risks. This situation certainly influences the application of these techniques.

Growing awareness of the role of risk in business activities, however, leads to searching new knowledge about risk identification tools, especially among the companies forming the core of any economy (MSMEs). Although the findings presented in the study cannot be generalized to the entire population, they seem to indicate a significant area for both theoretical and empirical research. This leads to further in-depth qualitative research in this field. It should be noted that the data contained in this paper is part of a larger study, and shows only the key issues of risk management in the Polish MSME sector. 
Iwona GORZEŃ-MITKA. Risk Identification Tools - Polish MSMES Companies Practices

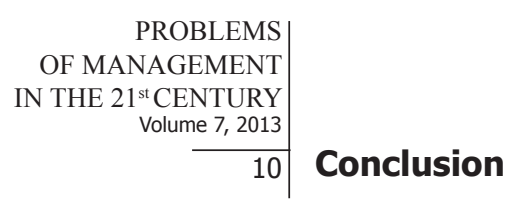

The business management literature has largely neglected the subject of risk management for SMEs. Therefore, the aim of this research was to explore the current state of risk management and to reveal the problems with implementing a risk management system in Polish MSMEs. The number of enterprises with established risk identification tools (or at least planning to establish it) is remarkably small. This suggests that MSMEs have a problem with this issue. It may be the result of a poor knowledge about it, usefulness or possibilities of use.

\section{References}

Beasley, M. S., Clune, R., Hermanson, D. R. (2005). Enterprise risk management: An empirical analysis of factors associated with the extent of implementation. Journal of Accounting and Public Policy, 24, 521-31. doi: 10.1016/j.jaccpubpol.2005.10.001

Bernstein, P. L. (1996). Against the Gods: The Remarkable Story of Risk New YorkChichesterBrisbaneToronto-Singapore.

Chapman, R. J. (2007). Simple tools and techniques for enterprise risk management. Joh Wiley \& Sons, Inc. New YorkChichester BrisbaneTorontoSingapore.

Economist Intelligence Unit (2010). Fall Guys: Risk Management in the Front Line. Independent Industry and Management Research. [On line] Accessed 15 December 2012] Available from Internet: http://www.businessresearch.eiu.com/fall-guys.html.

FERMA (2010). European Risk Management Benchmarking Survey, Available from Internet: < http:// www.ferma.eu/wp-content/uploads/2011/10/ferma-risk-management-benchmarking-survey2010.pdf $>$ [Accessed 15th December 2012]

Gorzeń-Mitka, I. (2007). Ryzyko w eksporcie. Metody i sposoby ograniczania. KeyText, Warszawa.

Gorzeń-Mitka, I. (2012). Risk Management in Polish Companies. In: Business and Management'2012. The 7th International Scientific Conference. Selected Papers. Vol. 2. May 10-11 2012, Vilnius, Lithuania. VGTU Publishing House "Technika", Vilnius.

GUS (2011). Zmiany strukturalne grup podmiotów gospodarki narodowej wpisanych do rejestru REGON, Warszawa. Available from: www.stat.gov.pl/cps/rde/xbcr/gus/PUBL_pgwf_zmiany_strukturalne_grup_podmiotow_Ipol_2011.pdf [Accessed 15th December 2011].

Hopkin, P. (2010). Fundamentals of Risk Management. Kogan Page, London.

ISO (2009a). Risk Management - Principles and Guidelines. ISO 31000:2009. International Standard, International Organization for Standardization, Available from: <http://www.lesia.insa-toulouse. fr/ motet/papers/_FDIS_31000_(E).pdf $>$. [Accessed 15th December 2011].

ISO (2009b). Risk Management-Vocabulary, ISO Guide 73:2009. International Standard, International Organization for Standardization. Available from: $<$ http://www.pqm-online.com/assets/files/standards/iso_iec_guide_73-2009.pdf> [Accessed 15th December 2011].

Karkoszka, T. (2013). Optimization of Quality, Environmental and Occupational Risk by the System and Technological Solution. Problems of Management in the $21^{\text {st }}$ Century, 6, 7-13.

Lam, J. (2003). Enterprise Risk Management. John Wiley \& Sons, Inc. New YorkChichester BrisbaneTorontoSingapore.

Liebenberg, A. P., Hoyt, R. E. (2003). Determinants of Enterprise Risk Management: Evidence from the Appointment of Chief Risk Officers. Risk Management and Insurance Review, 6, 37-52. doi: 10.1111/1098-1616.00019.

Martins, C. G., Morano, C. A. R., Ferreira, M. L. R., Haddad, A. N. (2011). Risk identification techniques knowledge and application in the Brazilian construction. Journal of Civil Engineering and Construction Technology, 2 (11), 242-252. Available online at http://www.academicjournals.org/ jcect. DOI:10.5897/JCECT11.024.

PARP (2010). Raport o stanie sektora matych i średnich przedsiębiorstw w Polsce $w$ latach 2008-2009, PARP, Warszawa.

Spedding, L., Rose, A. (2008). Business Risk Management Handbook. A sustainable approach. CIMA Publishing, Elsevier. 
Vandenberg, P. (2009). Micro, small and medium-sized enterprises and the global economic crisis: imVolume 7, 2013 pacts and policy responses, International Labour Office, Sustainable Enterprise Programme. Geneva, p.8. [On-line]. Available from: http://www.ioe-emp.org/fileadmin/user_upload/documents pdf/globaljobscrisis/ilorelateddocs/2009_June_SME_crisis_strategies_ILO.pdf [Accessed 15th December 2011].

Advised by Judita Stankute, SMC “Scientia Educologica”, Lithuania

Received: June 02, 2013

Accepted: June 24, 2013

Iwona Gorzeń-Mitka

PhD., Assistant Professor, Faculty of Management, Czestochowa University of Technology, Al. Armii Krajowej 19B, 42-201 Czestochowa, Poland.

Email: iwona.mitka@zim.pcz.pl

Website: http://www.zim.pcz.pl/profile/295,iwona-gorzen-mitka 